\title{
Correction to: Symptoms presented during emergency telephone calls for patients with spontaneous subarachnoid haemorrhage
}

Asger Sonne ${ }^{1 *} \mathbb{D}$, Sarita Egholm', Laurits Elgaard', Niklas Breindahl', Alice Herrlin Jensen', Vagn Eskesen 2,7, Freddy Lippert ${ }^{3,7}$, Frans Boch Waldorf ${ }^{4,5}$, Nicolai Lohse ${ }^{6,7}$ and Lars Simon Rasmussen ${ }^{1,7}$

\section{Correction to: Scand J Trauma Resusc Emerg Med (2021)}

\section{9:118}

https://doi.org/10.1186/s13049-021-00934-x

Following the publication of the original article [1], the authors informed as of an error in Figure 2: The term "persistently unconscious" had accidentally replaced "neck pain" in the third row under "Symptoms".

The correct figure is shown here below and has already been included in the original article. to the material. If material is not included in the article's Creative Commons licence and your intended use is not permitted by statutory regulation or exceeds the permitted use, you will need to obtain permission directly from the copyright holder. To view a copy of this licence, visit http://creativecommons.org/licenses/by/4.0/. The Creative Commons Public Domain Dedication waiver (http://creativeco mmons.org/publicdomain/zero/1.0/) applies to the data made available in this article, unless otherwise stated in a credit line to the data. 


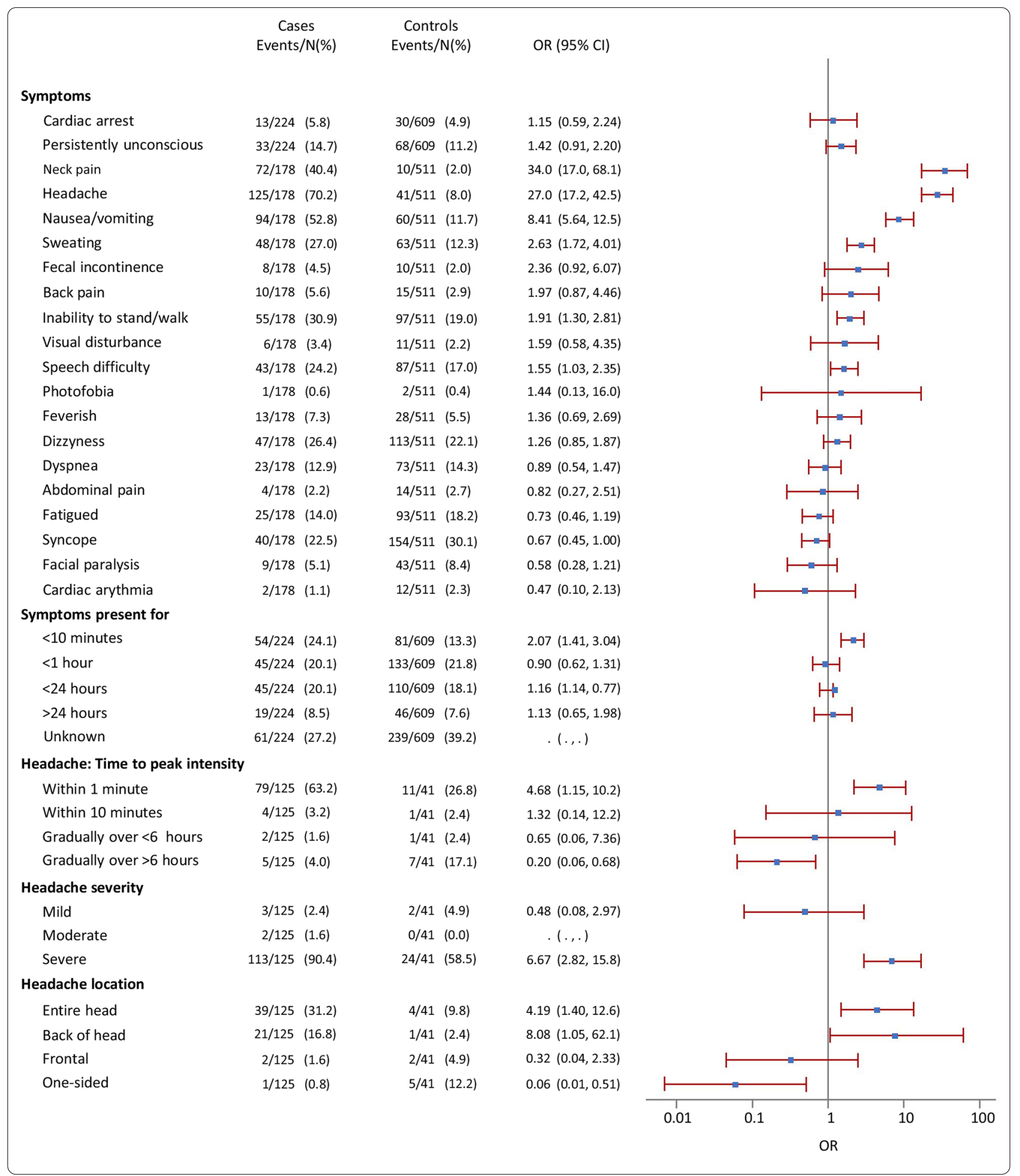




\section{Author details}

'Department of Anaesthesia, Section 6011, Center of Head and Orthopaedics, Rigshospitalet, Inge Lehmanns Vej 6, 2100 Copenhagen, Denmark. ${ }^{2}$ Department of Neurosurgery, The Neuroscience Centre, Rigshospitalet, University of Copenhagen, Copenhagen, Denmark. ${ }^{3}$ Copenhagen Emergency Medical Services, Copenhagen, Denmark. ${ }^{4}$ Research Unit of General Practice, Department of Public Health, University of Southern Denmark, Odense, Denmark.

${ }^{5}$ The Research Unit for General Practice and Section of General Practice, Department of Public Health, University of Copenhagen, Copenhagen, Denmark. ${ }^{6}$ Department of Emergency Medicine, Copenhagen University Hospital - Nordsjællands Hospital, Hillerød, Denmark. ${ }^{7}$ Department of Clinical Medicine, University of Copenhagen, Copenhagen, Denmark.

Published online: 14 October 2021

\section{Reference}

1. Sonne, et al. Symptoms presented during emergency telephone calls for patients with spontaneous subarachnoid haemorrhage. Scand J Trauma Resusc Emerg Med. 2021;29:118. https://doi.org/10.1186/ s13049-021-00934-X.

\section{Publisher's Note}

Springer Nature remains neutral with regard to jurisdictional claims in published maps and institutional affiliations.
Ready to submit your research? Choose BMC and benefit from:

- fast, convenient online submission

- thorough peer review by experienced researchers in your field

- rapid publication on acceptance

- support for research data, including large and complex data types

- gold Open Access which fosters wider collaboration and increased citations

- maximum visibility for your research: over $100 \mathrm{M}$ website views per year

At BMC, research is always in progress.

Learn more biomedcentral.com/submissions 